Egyptian Journal of Aquatic Biology \& Fisheries

Zoology Department, Faculty of Science,

Ain Shams University, Cairo, Egypt.

ISSN $1110-6131$

Vol. 23(2): 639 - 656 (2019)

www.ejabf.journals.ekb.eg

\title{
A study on growth, mortality and a biochemical growth indicator of Oreochromis niloticus in a Nile Canal, Egypt.
}

Khallaf, E.A.*, Alne-na-ei, A. A., El-Garawani, I.M. and Elgendy, R. G. Zoology Department, Faculty of Science, Minoufiya University, Shebeen Alkoom, Egypt. *Corresponding author: ekhallaf@yahoo.com

ARTICLE INFO

Article History:

Received: March28, 2109

Accepted: April 22, 2019

Online: April 28, 2019

Keywords:

Oreochromis niloticus

Molecular bioindicators

Growth

Mortality

RNA/DNA

\begin{abstract}
This study was carried out to examine growth and mortality and the efficiency of the ratio of RNA/DNA in characterizing growth of Oreochromis niloticus. Growth in weight with length of fish was predicted by the significant relationship: $\log \mathrm{W}(\mathrm{g})=-1.6696+3.1971 \log \mathrm{L}(\mathrm{cm})$. The value of the slope of that relationship was found to be the highest, when compared with other reported values in different localities, where rise in temperature in the period of study is suspected. The fish under study were found to fall in 5 age-groups. Seasonal variation of the condition coeffecient "K" showed a slight decrease on going from winter towards summer. The instantaneous total mortality was predicted as 1.4022 , and consequently survival rate was 0.2461 and mortality rate was more than 75 $\%$. The lower value of survival rate than that earlier reported study, was thought to be due to rise in temperature because of global warming. The ratio of RNA/DNA increased with increase of either age or length of fish, but declined at age $\mathrm{V}$, corresponding to the length of $24 \mathrm{~cm}$. This finding could be attributed to the effect of fishing recruitment which is covering the first 4 age-goups. Significant relationship between RNA/DNA and K ( $\left.\mathrm{r}^{2}=0.78\right)$, then with seasonal variation $\left(\mathrm{r}^{2}=0.81\right)$. Those relationships showed a rise in the molecular ration, and $\mathrm{K}$, during winter and decline in summer could be speculated as a compensation in growth after disturbance in growth during spawning period. Thus, the RNA/DNA ration variation could be tied to describing growth of $O$. niloticus, as well as seasonal variation effects.
\end{abstract}

\section{INTRODUCTION}

Tilapias are the main species that inhabit the River Nile, irrigation network and canals in Egypt. They represent over 70\% of the Egyptian fish landing, therefore it is considered the basis of fishing (Ishak et al., 1985; AL-Zahaby et al., 1987).

Nile tilapia (Oreochromis niloticus) can live longer than 10 years (GISD, 2012). Food availability and water temperature appear to be the limiting factors to their growth (Kapetsky and Nath, 1997). Optimal growth is achieved at $28-36^{\circ} \mathrm{C}$ and declines with decreasing temperature (Teichert-Coddington et al., 1997; FAO, 2012). The ability to vary their diet may also result in variation in growth (Bwanika et al., 2007). In aquaculture ponds, $O$. niloticus can reach sexual maturity at the age of 5-6 months (FAO 2012)

Growth and age structure are important to understanding of ecology and the dynamics of fish population (Chilton Beamish, 1982; Beamish and Medland, 1988). 
In subtropical regions, where there was a marked seasonal variation in temperature, Van Rensburg (1966) and Balon (1970) indicated that the annuli might be formed in a period from December to March. In the Egyptian waters, where the annuli would be seen clear in the fish scales or vertebrae in the month of April (Bishai and Labib, 1973; Azim, 1974; El-Atriby, 1976 ; Khallaf, 1977, 1988).

Earlier, authors used morphometric, histological and biochemical indices for examining, growth and nutritional condition of fish species. Measuring of total length and weight of fish sometimes does not give clear picture of growth status of fish. Currently the ratio of ribonucleic acid (RNA) concentration to deoxyribonucleic acid (DNA) concentration in body tissue is a useful indicator of nutritional condition and growth (Khallaf et al., 1993; Mathers et al., 1994; Clemmesen et al., 1997; Buckley et al., 1999; Caldarone et al., 2001; Gwak and Tanaka, 2001; Peck et al., 2003 ; Smith and Buckley, 2003).

This is based on the assumption that the amount of DNA, the primary carrier of genetic information, is stable under changing environmental situations within the somatic cells of a species, whereas the amount of RNA is directly involved in protein synthesis, is known to vary with age, life-stage, organism size, disease-state and with changing environmental conditions (Bulow, 1987).

The RNA/DNA ratio has proven to be a useful indicator of growth rate for freshwater and marine fish species (Bulow, 1987; Khallaf et al., 1993; Malloy and Targett, 1994; Rooker and Holt 1996; Fukuda et al., 2001; Peck et al., 2003; Caldarone, 2005; Mercaldo-Allen et al., 2006; Tanaka et al., 2008).

Consequently, this study was initiated to examine the relation of RNA/DNA in Oreochromis niloticus, and their efficiency in characterizing growth of this fish.

\section{MATERIALS AND METHODS}

Bahr Shebeen Canal is a semi-independent water ecosystem from the Nile that extended from Alrayah Almenofi near the Barrage. It extends as $80 \mathrm{~km}$ in length, $30 \mathrm{~m}$ in width and 2-3m in depth (Khallaf and Alne-na-ei, 1987).

\section{Collection of samples}

Fish were caught by trammel nets by fishermen during the day, at different location within $25 \mathrm{~km}$ length of Bahr Shebeen Canal during consecutive months from November 2017 to December 2018. Fish samples 146 were brought after capture to the laboratory and the following observations were recorded for fish:

Date of capture.

Total length and standard length of every fish to the nearest $\mathrm{cm}$

Total body weight to the nearest $\mathrm{g}$.

Fish scales (10-20 from each specimen) were taken from the left side of each fish from the region behind the pectoral fin between the dorsal fin and lateral line (Rounsefell and Everhart, 1953), and kept in envelopes for later examination.

Parts of pectoral muscle were kept frozen for later analysis.

These samples were labeled with records on date, sex, length and weight of fish.

\section{Growth}

The scales were cleaned in $10 \%$ solution of ammonium hydroxide for one day, then washed by distilled water, dried by filter paper, and mounted between two glass slides. Age determination was based on the examination of the scales from each fish by using a binuclear microscope at 10x magnification according to Lagler (1956). 


\section{Length-weight relationship} as follows:

The length-weight relationship was predicted as indicated by Le Cren (1951)

$$
\begin{array}{ll} 
& \log \mathrm{W}=\log \mathrm{a}+\mathrm{n} \log \mathrm{L} \\
\text { or } & \mathrm{W}=\mathrm{a} \mathrm{L}^{\mathrm{n}}
\end{array}
$$

Where:

$\mathrm{W}=$ fish weight in grams.

$$
\begin{aligned}
& \mathrm{L}=\text { fish standard length in centimeter. } \\
& \mathrm{a} \text { and } \mathrm{n}=\text { regression constants }
\end{aligned}
$$

\section{2- Condition factor:}

The condition coefficient "K" of the fish is based on the following relationship after Le Cren (1951) and Ricker (1975):

$\mathrm{K}=100 \mathrm{X} \mathrm{W} / \mathrm{L}^{3}$

Where:

$\mathrm{W}=$ fish weight in grams.

$\mathrm{L}=$ fish standard length in centimeter

Mortality rates

\section{Catch curve Methods}

Catch curves (Baranov, 1918) are described by an ascending left limb and descending right one. The straightness of this right limb, or any partition of it, which embraces the following assumptions:

The survival rate is steady with age.

The survival rate is the complement of mortality rate.

No variation in mortality with time.

Random samples are taking over the age -groups in question.

The age- groups in question were equal in numbers at the time of recruitment to the fishery.

Following Gulland (1969), the plot of Ln of frequency at different age-groups, and using the straight line for calculation where the slope would be "-Z". The calculation of survival and mortality rates are carried out as follows:

$\mathrm{S}=\mathrm{e}^{-\mathrm{z}}=1-\mathrm{A}$

Where:

$\mathrm{S}=$ Annual survival rate .

$\mathrm{A}=$ Annual mortality rate.

$\mathrm{Z}=$ Instantaneous mortality rate.

\section{Molecular investigations}

\section{Isolation of total nucleic acids from muscle tissues :}

\section{Determination of total RNA}

The electrophoretic pattern of nucleic acids was detected in tissue lysate according to Hassab El-Nabi et al. (2001) with some modifications had been introduced by El-Garawani and Hassab El-Nabi (2016) in which the direct staining of samples was done. Where, a piece of $40 \mathrm{mg}$ of the muscle tissue was homogenized and lysed with $150 \mu \mathrm{l}$ lysis buffer. After $24 \mathrm{~h}, 10 \mu \mathrm{l}$ with $10 \%$ loading buffer were loaded on $1.8 \%$ TBE-agarose gel.

\section{Determination of total genomic DNA}

Nucleic acid extraction was done according to extraction method of Aljanabi and Martinez (1997) with some modifications had been introduced by El-Garawani and Hassab El-Nabi (2016) in which the direct staining of DNA sample was done. Briefely, 20mg of muscle tissues were lysed in Eppendorf tubes with $500 \mu 1$ lysis 
buffer and gently were shaken. The mixture was incubated over night at $37^{\circ} \mathrm{C}$ then, $200 \mu 1$ of $4 \mathrm{M} \mathrm{NaCl}$ were added to the sample, then they were shaken and centrifuged at $10000 \mathrm{rpm}$ for $10 \mathrm{~min}$. The supernatant was transferred to new Eppendorf tube and then DNA was precipitated by $600 \mu \mathrm{l}$ cold isopropanol.The mix was inverted several times till fine fibers appeared and then the tubes were centrifuged for 10 minutes at $12000 \mathrm{rpm}$. The supernatant was removed and the pellets were washed with $500 \mu \mathrm{l}$ of $70 \%$ ethyl alcohol, then they were centrifuged at $12000 \mathrm{rpm}$ for 10 min. After centrifugation the alcohol was decanted or tipped out and the tubes plotted on Whatman paper to be dried. The pellets were resuspended in $30 \mu \mathrm{l}$ or appropriate volume of TE buffer (10 mMTris, $1 \mathrm{mM}$ EDTA, $\mathrm{pH} 8)$ at $37^{\circ} \mathrm{C}$ over night. The resuspended DNA was incubated for 30-60 minutes with $10 \mu 1$ loading mix (Rnase + loading buffer $)+1 \mu 1$ of ethidium bromide, and then loaded into the gel wells.

Determination of RNA/DNA ratio :

RNA/DNA ratios were different among tissues, and fish white muscles are most sensitive for nucleic acid measurements (Foster et al., 1993). Hence, RNA/DNA ratio was estimated in muscle tissues of the adult fish samples. The extracted DNA and RNA samples were electrophoresed in 1.8\% agarose gel (SigmaAldrich, Germany) and prepared in TBE buffer against DNA ladder (Thermo Scientific $^{\mathrm{TM}} \mathrm{O}^{\prime}$ Gene Ruler ${ }^{\mathrm{TM}}$, US). The intensity of DNA and RNA areas were measured by image $\mathbf{J}$ software, as a mean of optical density values.

\section{Gel preparation}

Gels were prepared with $1.8 \%$ electrophoretic grade agarose (Sigma-Aldrich, Germany) and $0.2 \%$ polyvinyl pyrolidine (Sigma-Aldrich, Germany). The agarose and PVP were boiled with tris borate EDTA buffer (1×TBE buffer; 89 mMTris, 89 $\mathrm{mM}$ boric acid, $2 \mathrm{mM}$ EDTA, $\mathrm{pH} 8.8)$. ethidium bromide $(0.5 \mu \mathrm{g} / \mathrm{ml})$ was added to the gel at $40{ }^{\circ} \mathrm{C}$. Gels were poured and allowed to solidify at room temperature for 1 hour before the samples were loaded. DNA was separated by horizontal electrophoresis with $1 \times$ TBE running buffer at a constant voltage $(50 \mathrm{~V})$ for 1.5 hour using small electrophoresis cell (Bio-Rad power pack 300, USA). DNA was visualized using a $312 \mathrm{~nm}$ UV light under a trans illuminator and gel was photographed using digital camera. The intensity of bands was measured by image $\mathbf{J}$ software as a mean of optical density values.

\section{RESULTS}

\section{Growth and mortality:}

\section{The length-weight relationships}

The length-Weight relationship is used to determine, among other biological parameters, variation in condition of $O$. niloticus.

The predicted formulae were found to be as follows:

$$
\begin{gathered}
\log \mathrm{W}=-1.6696+3.1971 \log \mathrm{L} \\
\text { Or } \mathrm{W}=0.0214 \mathrm{~L}^{3.1971}\left(\mathrm{r}^{2}=0.99\right)
\end{gathered}
$$

Where $\mathrm{L}=$ standard length of fish in $\mathrm{cm}, \mathrm{W}=$ weight of fish in $\mathrm{g}$, and $\mathrm{r}^{2}$ is the coefficient of determination.

This relationship is represented in Fig. 1. The high value of the coefficient of determination performs a good measure for how much of the variation in weight is correlated with variation in length. As indicated in Table 1, the b constant of various length-weight relationships at different localities, showed conspicuous variability. However, it reached here in this study the highest value (3.197). 


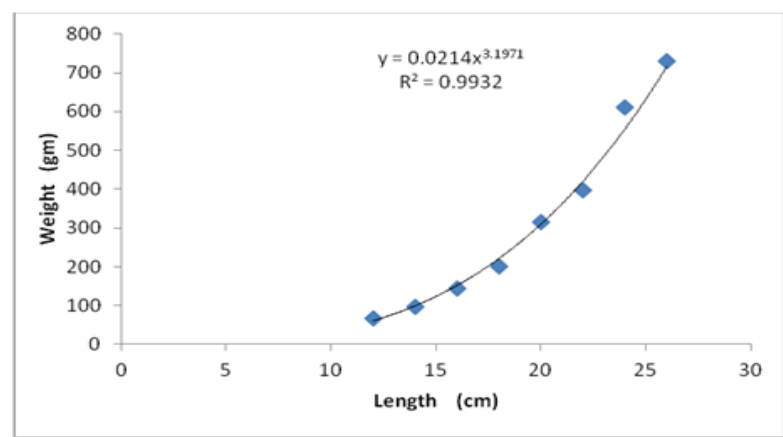

Fig. 1: Relationship between weight and standard length of $O$. niloticus.

Table 1 : Comparing Length-weight relationship b values of past works.

\begin{tabular}{|c|c|c|c|}
\hline Author & Year & Location & L - W slope b \\
\hline Khallaf & 1992 & Bahr Shebeen Canal & 2.79 \\
\hline Khallaf et al. & 1998 & Shanawan Drainage Canal & 2.68 \\
\hline Bakhoum and & 2002 & Lake Manzalah, Egypt. The less polluted & (region A) 2.75 \\
\hline Abdallah & & $\begin{array}{l}\text { one lies southwest (region A) and the } \\
\text { other highly polluted lies in southeast } \\
\text { (region B) of the Lake. }\end{array}$ & (region B) 2.95 \\
\hline Khallaf et al. & 2003 & $\begin{array}{c}\text { Shanawan, Drainage Canal (SDC), } \\
\text { AlMinufiya Province, Egypt, }\end{array}$ & 2.70 \\
\hline $\begin{array}{l}\text { Mortuza and Al- } \\
\text { Misned }\end{array}$ & 2013 & Wadi Hanifah, Riyadh, Saudi Arabia & 3.08 \\
\hline El-Kasheif et al. & 2015 & $\begin{array}{c}\text { El-Bahr El-Faraouny } \\
\text { Canal, Al-Minufiya Province, Egypt }\end{array}$ & 2.80 \\
\hline Khallaf et al. & 2016 & Bahr Shebeen Canal & 2.59 \\
\hline Karrar et al. & 2016 & White Nile, Sudan & 3.07 \\
\hline Shalloof and El- Far & 2017 & River Nile in Egypt & 3.02 \\
\hline Khallaf et al. & $\begin{array}{l}\text { Current } \\
\text { study }\end{array}$ & Bahr Shebeen Canal & 3.197 \\
\hline
\end{tabular}

\section{Seasonal variation of length - weight relationship}

Figure 2 illustrates seasonal variation of length-weight relationship of $O$. niloticus. It was found that, the highest value (3.7983) was recorded during autumn, and the lowest value (2.8069) was found during winter.

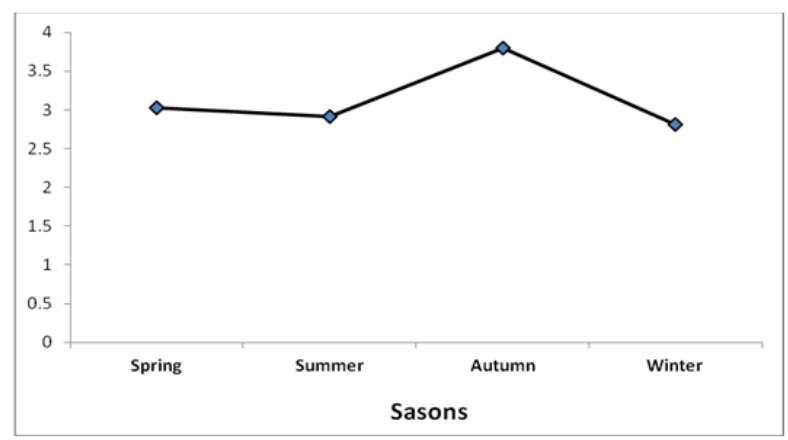

Fig. 2: Relationship between seasonal variation and length-weight slope of $O$. niloticus.

\section{Relationship between age and length and weight}

Figure 3 and Table 2 shows the relationship between age and standard length, which was found to be linear. As indicated $r^{2}$ reached 0.9548, predicting a good association between age and length of fish. Similarly, Fig. 4 shows that the 
relationship between age and weight was also found to be linear. As indicated $\mathrm{r}^{2}$ reached 0.879 , predicting a positive relationship between age and weight of fish.

Table 2 : Relationship between age and average standard length and average weight of $O$. niloticus.

\begin{tabular}{lccc}
\hline $\begin{array}{l}\text { Age of fish } \\
\text { (Years) }\end{array}$ & $\begin{array}{c}\text { Number of } \\
\text { Fish }\end{array}$ & $\begin{array}{c}\text { Average length }(\mathbf{c m}) \\
\text { (Mean } \pm \text { SD) }\end{array}$ & $\begin{array}{c}\text { Average weight (g) } \\
\text { (Mean } \pm \text { SDD) }\end{array}$ \\
\hline I & 30 & $13.82 \pm 1.17$ & $114.38 \pm 14.51$ \\
II & 63 & $14.54 \pm 1.28$ & $134.78 \pm 14.35$ \\
III & 40 & $17.37 \pm 1.40$ & $227.88 \pm 17.26$ \\
IV & 5 & $21.22 \pm 0.69$ & $414.17 \pm 17.32$ \\
V & 3 & $25 \pm 1.01$ & $708.837 \pm 38.83$ \\
\hline
\end{tabular}

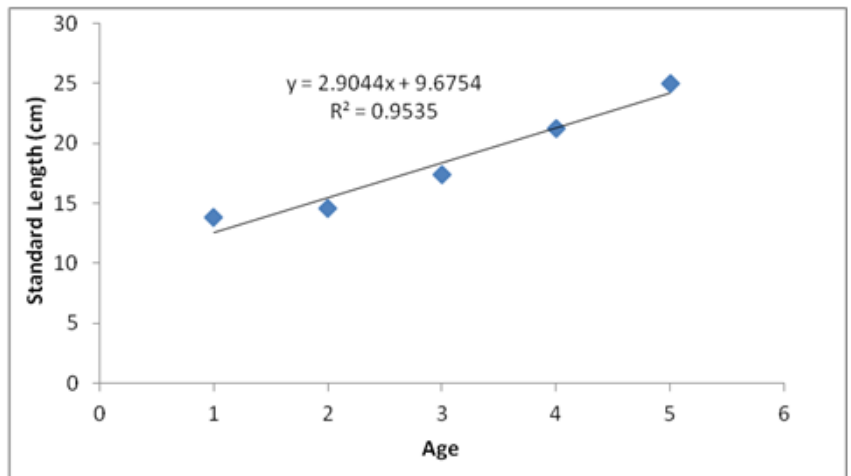

Fig. 3: Relationship between age and average standard length of $O$. niloticus.

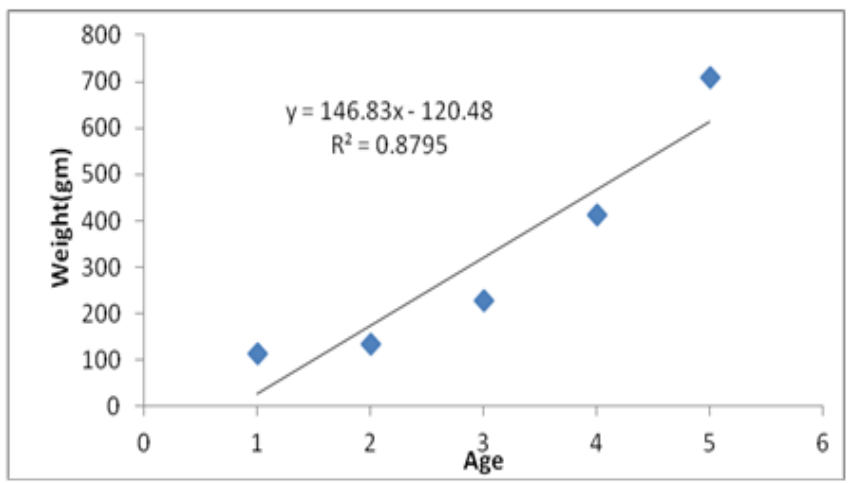

Fig. 4: Relationship between age and average weight of $O$. niloticus.

\section{Condition coefficient (K)}

\section{Relationship between $K$ and age}

The variation in K, differed with age as indicated in Fig. 5, the values of fish condition were comparable at age groups I, III and IV. However a conspicuous increase is noticed at age group II and age V.

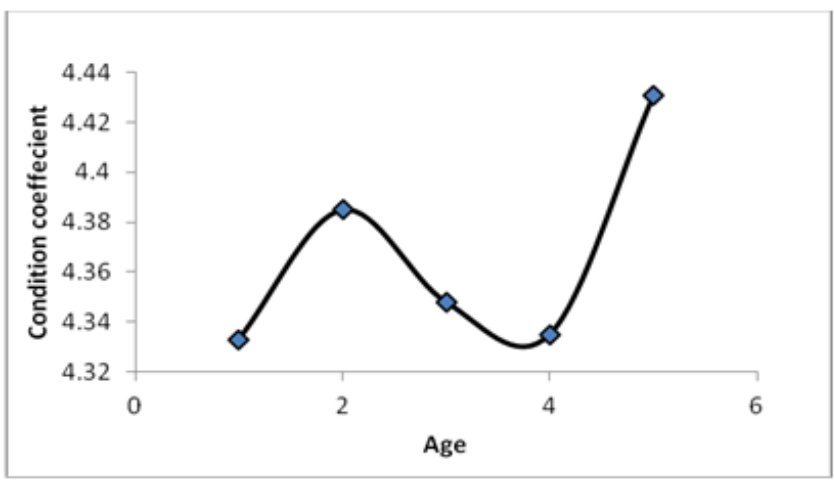

Fig 5: Relationship between condition coefficient and age of $O$. niloticus. 


\section{Variation of $\mathrm{K}$ with length}

As shown in Fig. 6, the variation of $\mathrm{K}$ with length indicates that, the fish condition increases as the fish grows larger, although there is wide variation in the value of $K$ with length which is reflected by the value of $r^{2}=0.6122$.

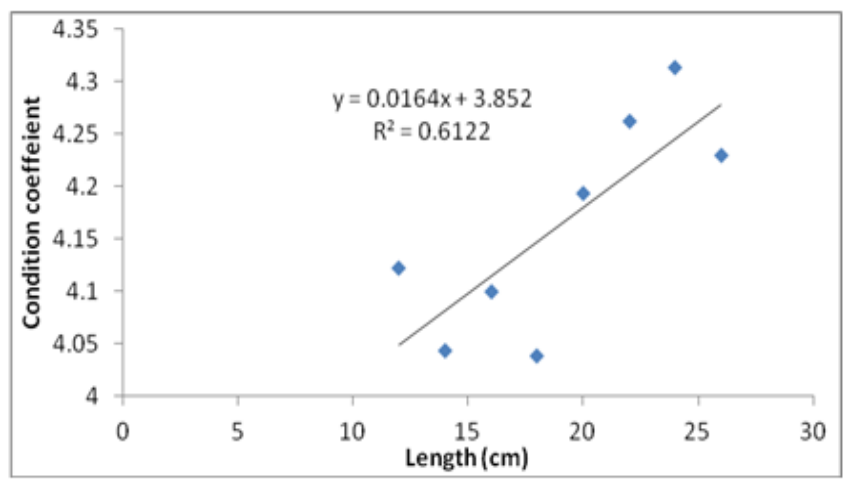

Fig. 6: Relationship between condition coefficient and length of $O$. niloticus.

\section{The seasonal variation of $K$}

Figure 7 showed that there is a strong correlation of change in $K$, with the highest value in winter then decline slightly in the following seasons. That relationship could be expressed linearly with a high value of $r^{2}=0.98$.

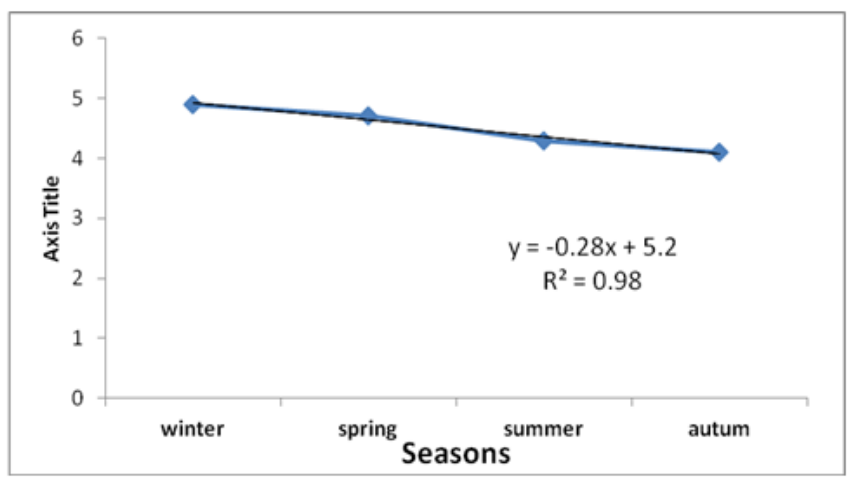

Fig. 7: Relationship between seasonal variations and condition coefficient of $O$. niloticus.

\section{Mortality}

Survival and mortality rates were calculated using the catch curve method. The descending limb of this curve (Fig. 8 and Fig. 9), followed a straight line between age-groups II-V, indicating a regular rate of mortality, and consequently was used for the calculation of mortality and survival rates. This could be represented as follows:

Ln $\mathrm{N}=7.0937-1.4022$ age (years). $\mathrm{r}^{2}=0.9719$.

where $\mathrm{N}$ is the number of fish caught.

Consequently, the instantaneous total mortality rate $\mathrm{Z}=-(-\mathrm{b})=1.4022$, and survival rate $S=e^{-z}=0.2461$, while the mortality rate A will be 0.7539 . 


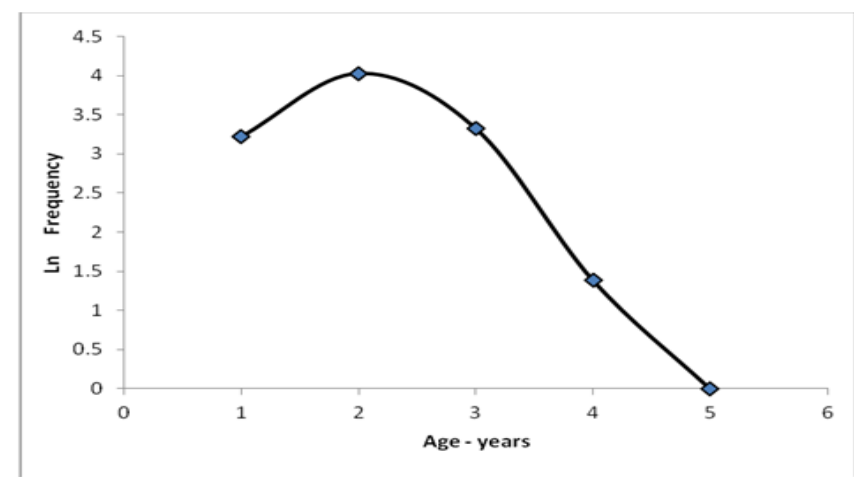

Fig. 8: Observed catch curve of $O$. niloticus.

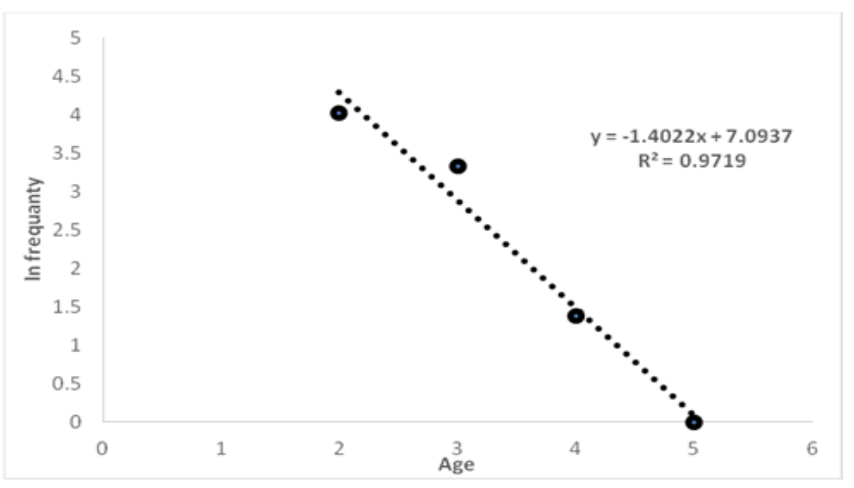

Fig. 9: Catch curve of $O$. niloticus.

\section{Molecular investigations}

\section{Relationship between RNA/DNA ratio and age groups of $O$. niloticus}

Figure 10 illustrates this relationship. It was found that, RNA/DNA ratio increased as fish increase in age (I - IV) then a decline occurred for older individuals at age $\mathrm{V}$.

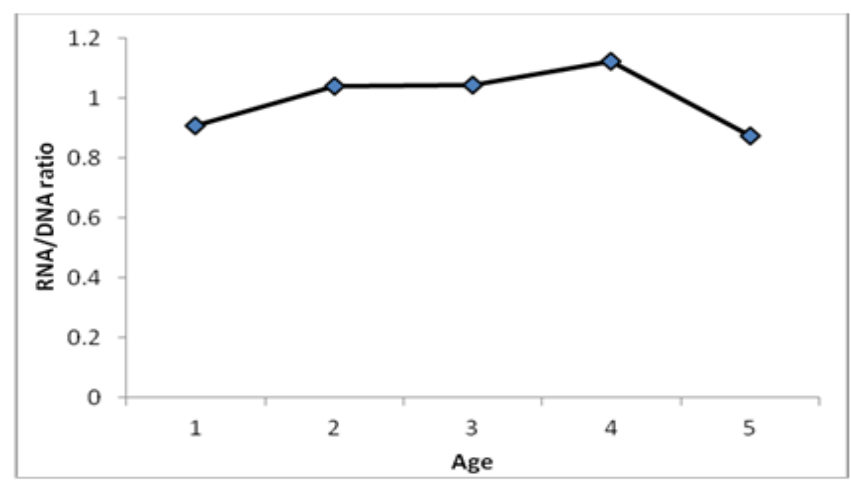

Fig. 10: Relationship between age and RNA/DNA ratio of $O$. niloticus.

\section{Relationship between RNA/DNA ratio and standard length}

Fig. 11 and Table 3 showed that the value of RNA/DNA ratio increased as fish increase in length (12-22) then reach the lower value at length 24 then slightly rise for fish more than that length. 
Table 3: Standard length and RNA/DNA ratio in muscle of Oreochromis niloticus.

\begin{tabular}{cccc}
\hline $\begin{array}{c}\text { Standard length } \\
(\mathbf{c m})\end{array}$ & $\begin{array}{c}\text { Number of } \\
\text { fishs }\end{array}$ & Average length & $\begin{array}{c}\text { RNA/DNA ratio } \\
\text { (Mean } \pm \text { SD) }\end{array}$ \\
\hline $11-12$ & 10 & 11.67 & $0.88 \pm 0.05$ \\
$13-14$ & 50 & 13.36 & $0.998 \pm 0.13$ \\
$15-16$ & 44 & 15.16 & $1.02 \pm 0.12$ \\
$17-18$ & 16 & 17.08 & $1.00 \pm 0.08$ \\
$19-20$ & 10 & 19.61 & $1.06 \pm 0.06$ \\
$21-22$ & 6 & 21.05 & $1.13 \pm 0.09$ \\
$23-24$ & 7 & 24 & $0.85 \pm 0.07$ \\
$25-26$ & 3 & 26 & $0.91 \pm 0.01$ \\
\hline
\end{tabular}

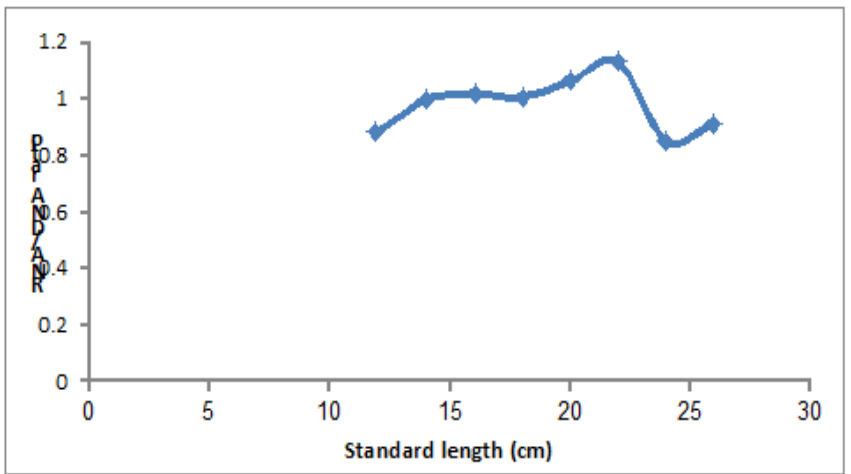

Fig. 11: Relationship between standard length and RNA/DNA ratio in muscle of $O$. niloticus.

\section{Relationship between RNA/DNA ratio and change in weight of fish}

As indicated in Fig. 12, such correlation was week $\left(\mathrm{r}^{2}=0.2068\right)$. It showed irregularities for RNA/DNA ratio with weight.

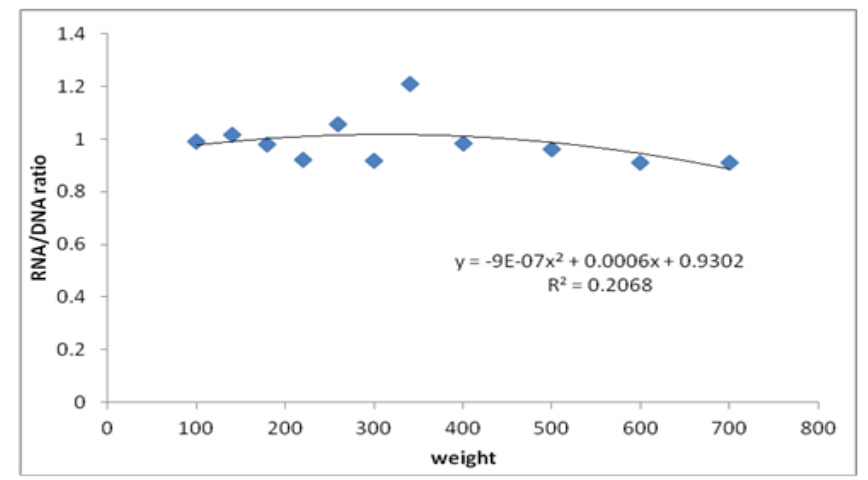

Fig. 12: Relationship between weight and RNA/DNA ratio in muscle $O$. niloticus.

\section{Change in RNA/DNA ratio with condition coefficient}

A stronger relationship is found $\left(\mathrm{r}^{2}=0.781\right)$ in Fig. 13 this indicates low variability and complicated the change in RNA/DNA ratio with Condition of fish.

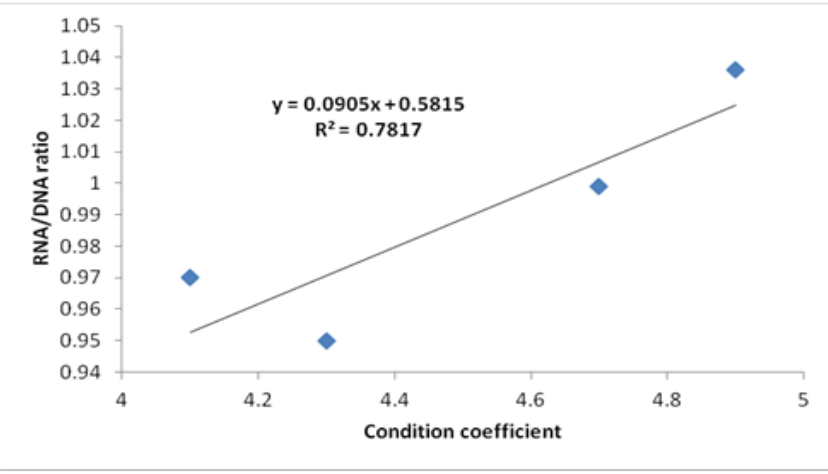

Fig. 13: Relationship between condition coefficient and RNA/DNA ratio in muscle of $O$. niloticus. 


\section{Seasonal variation of RNA/DNA :}

Fig. 14 illustrates this relationship. The highest value of 1.0563 was recorded in winter and the lowest value of 0.94 was during summer. However, it followed a powerful relationship with

$\mathrm{r}^{2}=0.807$.

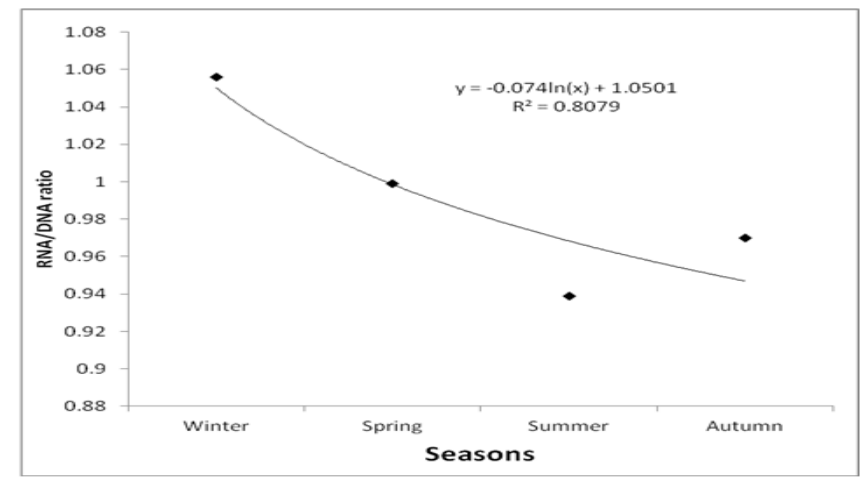

Fig. 14: Seasonal variation and RNA/DNA ratio in muscle of $O$. niloticus

\section{DISCUSSION}

The fish,Oreochromis niloticus, is highly recommended as one of the successful cultured fish due to their excellent growth rates even on low protein diets. Their success is also due to their tolerance of wider range of environmental conditions. In addition, those characters made them the most used fish in electric power stations cooling ponds. Moreover, they are highly and widely acceptable as food, being of high delicacy, as considered by many people throughout the world. Consequently, special interest has been given to study the biological and environmental conditions related to the improvement of tilapia production (Balirwa, 1992; Khallaf et al., 2003, Barriga-Sosa et al., 2004).

In the present study, the relationship between length and weight of O.niloticus was calculated as 3.1971 showed positive allometric growth pattern. This mean fish is growing faster in weight than length. Ricker (1971) reported that the values of " $n$ " other than 3 indicated allometric growth, i.e., if n 3, the fish becomes heavier for its length as it grows larger. If the fish gets thinner, $n$ will be less than 3 . Le Cren (1951) recorded that obedience to cube law (isometric growth, $b=3$ ) is rare in a majority of fishes. This mean that the fish in better condition in Bahr Shebeen Canal through out the study period.

Table 1, summarized the different length-weight parameter $b$ invarious localities by a number of authors. That parameter varied between 2.67 to 3.17. It is apparent that the difference occur according to variation in areas of study. However, according to Khallaf et al. (2016), during November 2014 to November 2015, in the same canal, the b value was 2.78 as compared to the predicted value of 3.197 in this study. Such variation might be due to data difference, or due to the effect of rise in temperature and its effect on growth of tilapias.

Earlier, in a comparative study on L-W relationships of $O$. niloticus and $O$. aureus in polluted and non-polluted parts of Lake Mariut, Egypt, it was reported by Bakhoum (1994). that there were highly significant variations of L-W relationships of both species in polluted and non-polluted parts of the lake. Similarly, Khallaf et $a l .$, (2003) reported differences in L-W relationships of $O$. niloticus in a polluted canal compared with those of other authors in different localities and times. These 
differences were attributed to the effect of eutrophication and pollution on growth and other biological aspects of $O$. niloticus.

Differences in $b$ values can be ascribed to one or a combination of factors including differences in the number of specimens examined, location and season effects and distinctions in the observed length ranges of the specimens caught and the duration of sample collection (Moutopoulos and Stregiou, 2002).

According to Goncalves et al. (1997) and Ozaydin et al. (2007). the parameter (b) may vary seasonally, daily, or between habitats, therefore, slight variations were observed in growth coefficient (b) of O. niloticus in seasons which was observed, too, in this study.

In the present study, it was observed that the seasonal variation of $(\mathrm{K})$ of $O$. niloticus is fluctuating throughout the year. This could be attributed to seasonal variation of food availability, feeding rate, gonad development and spawning period (Bagenal and Tesch, 1978; Petrakis and Stergiou, 1995; Moutopoulos and Stergiou, 2002). The condition factor (K) reflects, through its variations, information on the physiological state of the fish in relation to its welfare. From a nutritional point of view, there is an accumulation of fat and gonads development (Le Cren, 1951).

The present study revealed that, the values of condition factor $(\mathrm{k})$ in summer were lower than the values in spring. In summer, after the breeding season, we found fish with lower condition, and most of them were spent. Spawning is a physically demanding and stressful period, which can affect also immune function (Schreck, 1981; Kortet et al., 2003). In spite of that, summer water temperature is optimal for growing and the greatest feeding activity starts (Penttinen and Holopainen, 1992; Holopainen et al., 1997), but the condition of O. niloticus increased reaching the highest value in winter. This might be due to interference of higher temperature during summer by the effect of climate change, an effect will be examined in another study. According to NASA, the summer of the years 2013 to 2018 are the highest in recorded weather history.

Based on present results, O. niloticus in Bahr Shebeen Canal had mean seasonal $\mathrm{K}$ values of greater than 4 in all the seasons sampled, an indication of general well-being and stable physiological status of the fish at study period.

According to Canonico et al. (2005), O. niloticus is known to adapt readily to a range of environmental factors such as salinity, low oxygen levels and can feed at different tropic levels when need arises. Deekae et al. (2010) noted that several factors affect the condition factor of fishes. These range from feeding, spawning, food nutrient composition and fat accumulation. The variations of condition factor (K) in fish according to King (1995) may be due to food abundance, adaptation to the environment and gonadal development. Pollution was also seen to affect the condition factors of O. niloticus in lake Mariut, Egypt (Bakhoum, 1994). Variations in condition factor with seasons and pollution has also been documented by Khallaf et al., (2003) in Shanawan drainage canal in Egypt.

In the present study, the fish condition was found to increase as the fish grows larger in length and the value of $\mathrm{K}$ ranged from 4.03 to 4.41 . This may be attributed to sexual maturation and active spawning of the larger fish (El-Agami, 1988). This is in agreement with the finding by Hadi (2008). On the other hand, many authors reported that the fish condition $(\mathrm{K})$ decreased as the fish grows larger (Ricker, 1975; Wootton, 1992; Khallaf et al., 2003; Abowei, 2010).

Mortality and survival rates are very important in relation to various controlling parameters as growth, reproduction and fishing as indicated by Ricker (1975). He also indicated that, if there is fishing is going on in a fishery, it is 
considered the main cause of mortality. In this study, "Z", the instantaneous mortality rate was found to be 1.4022 , and consequently survival rate was $24.61 \%$. This value is conspicuously lower than that predicted (43\%) by Khallaf et al. (2018) for the same species in the same canal during the period of 2014 to 2015 . This decline in survival rate is questionable, although climate change is susceptible, but needs further investigation.

Temperature was incorporated into growth-ratio models reported by Malloy and Targett (1994), Caldarone et al. (2003), Peck et al. (2003) and Mercaldo-Allen et al. (2006). In these models, the RNA/DNA ratio consistently varied with temperature in a linear manner. However, during our study, the RNA/DNA ratio was curvilinear correlated with temperature. Such relationship could not explain the variability in the RNA/DNA ratio, where it increased with elevated temperature. This is in agreement with findings by Wang et al. (2017).

In accordance, Ramirez et al. (2004) provided information about effect of seasonal variation on RNA/DNA ratio and growth rates of sardine larvae, since temperature has a positive effect on growth rates but it has a negative effect on the RNA/DNA ratio.

However, fish are poikilotherms, whose metabolic processes are influenced by ambient temperature. The synthesis of RNA and protein would be expected to accelerate as temperature increases, and consequently rise in RNA/DNA ratio (Mathers et al., 1993; Canino, 1994).

The increase of muscular RNA/DNA ratio during winter and autumn, where spawning ceases during these seasons, might be compensatory mechanism for the cost of reproduction on the account of other vital processes like growth. This is in agreement with the finding by Khallaf et al. (1993).

In the present study, there was a decrease of muscular RNA/DNA ratio during summer. Also similar results have been observed by Bulow et al. (1978) and Khallaf et al. (1993). They attributed the depression in summer to the high maintenance energy requirements associated with high temperature and reduced food assimilation efficiency coupled with biochemical pathway shift which occur during periods of high temperature and reduced dissolved oxygen levels as indicated also by Cech and Wohlschlag (1975).

When age is considered, RNA/DNA ratio increased as the fish become older, with an exception at age 5. This is similar to the finding of Buckley and Bulow (1987) and Mourya et al (2007) who reported that the ratio was higher in older fish compared to younger ones.

In contrast, Haines (1973) found that age of fish was found to have an important effect on RNA/DNA ratio, being higher in younger fish in 1-year-old fish than in 2-year-old fish.

Rooker and Holt (1996) and Iglesias et al. (2002) found that RNA/DNA ratios of larval were affected by age and size. During our study, the RNA/DNA ratio of white muscle tissue increased as length of fish increases, with a rise in its value at a length of about $22 \mathrm{~cm}$, to decline at a length of $24 \mathrm{~cm}$. This matches what is noticed for the variation of RNA/DNA ratio at age 5, as well as variation in condition coefficient with either age or length. As observed here the frequency of number of fish caught, fishing is effective on the range of sizes and ages younger than age 4, or lower than a length of $22 \mathrm{~cm}$. 


\section{REFERENCES}

Abowei, J.F.N. (2010): The condition factor, length-weight relationship and abundance of Ilisha africana (Block, 1795) from Nkoro River Niger Delta, Nigeria. Adv. J. Food Sci. Technol., 2(1): 6-11.

Aljanabi, S.M. and Martinez, I. (1997). (Universal and rapid salt-extraction of high quality genomic DNA for PCR-based techniques). Nucleic Acids Res., 25(22): 4692-4693.

Al-Zahaby, A. S.; El-Agamy, A. E.; El-Serafy, S. S. and Badawy, E. A. (1987). Preliminary observation on the relative growth and production of Tilapia species cultured in cages at three stocking densities. Qatar Univ. Sci. Bull., 7: 343-361.

Azim, M. Ezz El-Din (1974). Biological studies on Tilapia nilotica L. and Tilapia galilaea Art. in Lake Nasser. M. Sc. Thesis, Fac. Sci., Alexandria Univ., Egypt, 172 pp.

Bagenal, T.B. and Tesch, F.W. (1978). Age and growth. In: Methods for assessment of fish production in fresh waters, (Bagenal, T., Ed.). Oxford, Blackwell Sci. Publ., IBP Handbook No. 3, 3rd ed., pp., $101-136 .$.

Bakhoum, S.A. (1994). Comparative study on length-weight relationship and condition factors of the genus Oreochromis in polluted and non-polluted parts of Lake Mariut, Egypt. Bull. Natl. Inst. Oceanogr. \& Fish., Egypt, 20(1): 201210.

Bakhoum Sh. A. and Abdallah, M. (2002): Study to detect impacts of pollution on

fishery biology of tilapias in Lake Manzalah, Egypt. . J. KAU: Mar. Sci., 13: 147160.

Balirwa, J.S. (1992). The evolution of the fishery of Oreochromis niloticus in Lake Victoria. Hydrobiologia, 232: 85-89.

Balon, E.K. (1970). Age and growth of Hydrocynus vittatus (Castelnau, 1861) in Lake Kariba, Sinazongwe area. Fish. Res. Bull. Zambia, 5: 89-118.

Baranov, F. I. (1918). On the question of the biological basis of fisheries. NauchnyiIs sledovatelskii Ikhtiologicheskii Institut, Izvestiia, 1(1): 81-128.

Barriga-Sosa, I.A.; Jimenez-Badillo, M.D.L.; Ibanez-Aguirre, A.L. and ArredondoFigueroa, J. L. (2004). Variability of Tilapias (Oreochromis spp.) introduced in Mexico: morphometric, meristic and genetic characters. J. Appl. Ichthyol., 20: 7-14.

Beamish, F.W.H. and Medland, T.E. (1988). Age determination for lampreys. Trans. Am. Fish. Soc., 117(1): 63 -71.

Bishai, H.M. and Labib, W. (1973). Age and growth of mirror carp (Cyprinus carpio L.) at Serow Fish Farm, Egypt. Bull. Inst. Oceanogr. \& Fish., Egypt, 3: 395418.

Buckley, L. J. and Bulow, F. J. (1987). Techniques for the estimation of RNA, DNA and protein in fish. Hydrobiologia, 250: 105-109.

Buckley, L.J.; Caldarone, E.M. and Ong, T.L. (1999). RNA-DNA ratio and other nucleic acid based indicators for growth and condition of marine fishes. Hydrobiologia, 401: 265-277.

Bulow, F. J. (1987). RNA-DNA ratios as indicators of growth rates in fish: a review. In: Summerfelt RC, Hall GE (eds) Age and growth of fish. The Iowa State University Press, Ames, Iowa., p. 45-64. 
Bulow, F.J.; Coburn, C.B. and Cobb, C.S. (1978). Comparison of two Bluegill populations by means of the RNA - DNA ratio and liver somatic index. Trans. Am. Fish. Soc., 107 (6): 799 - 803.

Bwanika, G.N.; Murie, D.J. and Chapman, L.J. (2007). Comparative age and growth of Nile tilapia (Oreochromis niloticus L.) in lakes Nabugabo and Wamala, Uganda. Hydrobiologia, 589: 287-301.

Caldarone, E.M. (2005). Estimating growth in haddock larvae, Melanogrammus aeglefinus from RNA DNA ratios and water temperature. Marine Ecology Progress Series, 293: 241-252.

Caldarone, E.M.; St. Onge-Burns, J.M. and Buckley L. J. (2003). Relationship of RNA/DNA ratio and temperature to growth in larvae of Atlantic cod Gadus morhua. Mar. Ecol. Prog. Ser., 262: 229-240.

Caldarone, E.M.; Wagner, M.; St. Onge-Burns, J. and Buckley, L.J. (2001). Protocol and guide for estimating nucleic acids in larval fish using a fluorescence microplate reader. Ref Doc 01-11:1-22. National Marine Fisheries Service, Woods Hole, MA. Also available at: www.nefsc.noaa.gov/nefsc/publications/crd/crd0111/crd0111.pdf.

Canino, M.F. (1994). Effects of temperature and food availability on growth and RNA/DNA ratios of walleye Pollock Theragra chalcogramma (Pallas), eggs and larvae. J. Exp. Mar. Biol. Ecol., 175(1): 1-16.

Canonico, G.C.; Arthington, A.; McCrary, J. K. and Thieme, M. L. (2005). The effects of introduced tilapias on native biodiversity. Aquat. Conserv., 15: 463483.

Cech, J. J. and Wohlschlag, D. E. (1975). Summer growth depression in the striped mullet, Mugil cephalus. L. Contrib. Mar. Sci., 19: 91-100.

Chilton, D.E. and Beamish, R.J. (1982). Age determination methods for fishes studied by the Ground fish program at the pacific Biological Station. Can. Spec. Publ. Fish. Aquat. Sci., 60: 102p.

Clemmesen, C.; Sanchez, R. and Wongtschowski, C. (1997). A regional comparison of the nutritional condition of SW Atlantic anchovy larvae, (Engraulis anchoita) based on RNA/DNA ratios. Arch. Fish. Mar. Res., 45(1): 17- 43.

Deekae, S.N.; Chukwu, K.O. and Awotogha, G. (2010). Length-weight relationship and condition factor of Alestis alexandrius (Geoffrey Saint-Hillarie 1817) in Bonny River, Nigeria. J. Agricul. Res. Policies, 5(4): 16-18.

El-Agami, A.E. (1988). Age determination and growth studies of Gerres oyena (Forsk) in the Arabian Gulf waters. Mahasagar, 21(1): 23-34.

El-Atriby, S. Gh. (1976). Bilogical studies on Lates niloticus Cuv. \& Val. From Lake Nasser. M.Sc. Thesis, Fac. Sci., Alexandria Univ.

El-Garawani, I.M. and Hassab El-Nabi, S.E. (2016). (Increased sensitivity of apoptosis detection using direct and staining method and integration of acridine orange as an alternative safer fluorescent dye in agarose gel electrophoresis and micronucleus test). CJPAS., 10(2): 3865-3871.

El-Kasheif, M.A.; Authman, M.M.N.; Al-Ghamdi, F.A.; Ibrahim, S.A. and El-Far, A.M. (2015). Biological Aspects and Fisheries Management of Tilapia Fish Oreochromis niloticus (Linnaeus, 1758) in El-Bahr El-Faraouny Canal, AlMinufiya Province, Egypt. J. Fish. Aquat. Sci., 10(6): 405-444.

FAO. (2012). Cultured aquatic species information Programme. Oreochromis niloticus. cultured aquatic species information programme. text by Rakocy, J. E. in: FAO Fisheries and Aquaculture Department [online]. Rome. Updated 18 February 2005. [cited 11 September 2012]. 
Foster, A.R.; Houlihan, D.F. and Hall, S.I. (1993). Effects of nutritional regime on correlates of growth rate in juvenile Atlantic cod (Gadus morhua): comparison of morphological and biochemical measurements. Can. J. Fish. Aquat. Sci., 50: $502-512$.

Fukuda, M.; Sako, H.; Shigeta, T. and Shibata, R. (2001). Relationship between growth and biochemical indices in laboratory-reared juvenile Japanese flounder (Paralichthys olivaceus) and its application to wild fish. Mar. Ecol. Prog. Ser., 138: 47-55.

GISD (2012). Global Invasive Species Database - Oreochromis niloticus_Available from: http://www.issg.org/database/species/ecology.asp?si=1322\&fr=1\&sts=sss\&lang=EN

Goncalves, J.M.S.; Bentes, L.; Lino, P.G.; Ribeiro, J.; Canario, A.V.M. and Erzini, K. (1997). Weight-length relationships for selected fish species of the smallscale Demersal Fisheries of the South and South-West Coast of Portugal. Fish. Res., 30: 253-256.

Gulland, J.A. (1969). Manual of methods for fish stock assessment - Part 1. Fish population analysis. FAO Rome Man.Fishe. Sci., No. 4: 154pp.

Gwak, W.S. and Tanaka, M. (2001). Developmental change in RNA: DNA ratio of fed and laboratory reared Japanese flounder larvae and juveniles, and its application to assessment of nutritional condition for wild fish. J. Fish Biol., 59(4): 902-915.

Hadi, A. A. (2008). Some observation on the age and growth of Tilapia zillii (Gervais, 1848) in Umhfein Lake (Libya). J. Sci \& Its Applications, 2 (1): 1221.

Haines, T.A. (1973). An evaluation of RNA-DNA ratio as a measure of long-term growth in fish populations. J. Fish. Res. Board Can., 30(2): 195-199.

Hassab-El-Nabi, S.E.; Mohamed, A.H. and Osman, G.Y. (2001). Estimation of RNA electrophortic pattern as an indicator of pollution in Biomphalaria alexandrina snails treated with certain plant growth regulators, a herbicide, and lead acetate. J. Union Arab Biol. 15(A): 467-486.

Holopainen, I.J.; Tonn, W.M. and Paszkowski, C. A. (1997). "Tales of two fish: The dichotomous biology of crucian carp (Carassius carassius (L.)) in northern Europe". Ann. Zool. Fennici, 34(1): 1-22.

Iglesias, M.; Morales, B.; Massutí, S. and Busquets, X. (2002). An attempt to determine variability of RNA/DNA ratios during Dicentrarchus labrax larval development. Boll. Soc. Hist. Nat. Balears., 45: 15-20.

Ishak, M.M.; Al-Sayes, A.A and Talaat, K.M. (1985). Tilapia fisheries in Lake Borollus, Egypt. Kuwait Bull. Sci. Res., 6: 225-242.

Kapetsky, J.M. and Nath, S.S. (1997). A strategic assessment of the potential for fresh water fish farming in Latin America. COPESCAL Technical Paper.No. 10. Rome, FAO. 128p.

Karrar, A.M.H.M.; Elkareem, M.M.E.A. and Ali, A.K.S. (2016). Length-Weight Relationship and Condition Factor of Nile Tilapia [Oreochromis niloticus (Trewavas)] from White Nile, Sudan. ENRIJ., 1(1):77- 84.

Khallaf, E.A. (1977). Studies on family Schilbeidae from Lake Nasser. M.Sc. Thesis, Fac. Sci., Al-Azhar Univ., Egypt.

Khallaf, E.A. (1988). Effect of impoundment on the growth and fishery of Bagrus docmac in Lake Nasser. Regulated Rivers: Res. and Manag., 2: 547-552.

Khallaf, E.A. (1992). Evaluation of the fisheries of Oreochromis niloticus in Bahr Shebeen Canal- Nile Delta, Egypt. J. Egypt. Ger. Soc. Zool., 7(B): 27-44. 
Khallaf, E.A. and Alne-na-ei, A.A. (1987). Feeding ecology of Oreochromis niloticus (Linnaeus) \& Tilapia zillii (Gervias) in a Nile Canal. Hydrobiology, 146: 57 - 62.

Khallaf, E.A.; Bayomy, M.F.F. and Ghaber, N. (1993). Growth, and mortality of Clarias lazera (Cuv. \& Val.) in Bahr Shebeen Nile Canal, and use of some biochemical parameters as indicators of growth. J. Egypt. Ger. Soc. Zool., 10(B): 39-59.

Khallaf, E. A.; Galal, M. and Authman, M. (1998). Assessment of heavy metals pollution and their effects on Oreochromis-niloticus in aquatic drainage canals. J. Egypt. Ger. Soc. Zool., 26(B): 39-74.

Khallaf, E.A; Galal, M. and Athuman, M. (2003). The biology of Oreochromis niloticus in a Polluted Canal. Ecotoxicology, 12: 405-416.

Khallaf, E. A.; Alnenaei, A.A. and Elgindy, R. M. (2016). Fish Biology and Fishery of Oreochromis niloticus in Bahr Shebeen Canal, Delta of Egypt. Egypt. J. Aquat. Biol. \& Fish., 20 (4): 83-88.

Khallaf, E. A.; Autman,M.M., Galal, M. and R. A. Zaid (2018). A comparative biological study on Oreochromis niloticus from two Nilotic Canals in the Delta of Egypt. Egyptian Journal of Aquatic Biology \& Fisheries, 22(5): 39 - 63.

King, M. (1995). Fisheries biology, assessment and management. Fishing News Books, Oxford, England.,341 p.

Kortet, R.; Taskinen, J.; Sinisalo, T. and Jokinen, I. (2003). "Breeding-related seasonal changes in immunocompetence, health state and condition of the cyprinid fish, Rutilus rutilus, L." Biol. J. Linnean Soc., 78(1): 117-127.

Lagler, K. F. (1956). Fresh water fishery biology. W. M. C. Brown Co. Dubuque, Iowa, USA, $421 \mathrm{pp}$.

Le Cren, E.D. (1951). The length-weight relationship and seasonal cycle in gonad weight and condition in the perch (Perca fluviatilis). J. Anim. Ecol., 20(2): 201-219.

Malloy, K.D. and Targett, T.E. (1994). The use of RNA: DNA ratios to predict growth limitation of juvenile summer flounder (Paralichthys dentatus) from Delaware and North Carolina estuaries. Mar. Bioi., 118(3): 367-375.

Mathers, E.M.; Houlihan, D.F. and Burren, L.J. (1994). RNA, DNA and protein concentrations in fed and starved herring Clupea harengus larvae. Mar. Ecol. Prog. Ser., 107: 223- 231.

Mathers, E.M.; Houlihan, D.F.; McCarthy, I.D. and Burren, L.J. (1993). Rates of growth and protein synthesis correlated with nucleic acid content in fry of rainbow trout, Oncorhynchus mykiss: effects of age and temperature. J. Fish Biol., 43(2): 245-263.

Mercaldo-Allen, R.; Kuropat, C. and Caldarone, E.M. (2006). A model to estimate growth in young-of-the-year tautog, Tautoga onitis, based on RNA/DNA ratio and seawater temperature. J. Exp. Mar. Biol. Ecol., 329(2): 187-195.

Mortuza, M.G. and Al-Misned, F.A. (2013). Length-weight relationships, condition factor and sex-ratio of Nile tilapia, Oreochromis niloticus in Wadi Hanifah, Riyadh, Saudi Arabia. World J. Zool., 8 (1): 106-109.

Mourya, T. C.; Krishna, G. and Chaudhari, A. (2007). Estimation of RNA/DNA ratio in two North-Indian natural populations of mahseer (Tor tor), and its relationship with growth and hyrobiology. J. Indian Fish. Assoc., 34: 39- 46.

Moutopoulos, D.K. and Stergiou, K.I. (2002). Length-weight and length-length relationships of fish species from the Aegean Sea (Greece). J. Appl. Ichthyol., 18(3): 200-203. 
Özaydın, O.; Uçkun, D.; Akalın, S.; Leblebici, S. and Tosunoğlu, Z. (2007). Lengthweight relationships of fishes captured from Izmir Bay, Central Aegean Sea. J. Appl. Ichthyol., 23(6): 695-696.

Peck, M.A.; Buckley, L.J.; Caldarone, E.M. and Bengston, D.A. (2003). Effects of food consumption and temperature on growth rate and biochemical-based indicators of growth in early juvenile Atlantic cod (Gadus morhua) and haddock (Melanogrammus aeglefinus). Mar. Ecol. Prog. Ser., 251: 233-243.

Penttinen, O-P. and Holopainen, I. J.(1992). Seasonal feeding activity and ontogenetic dietary shifts in crucian carp, Carassius carassius. Env. Biol. Fish., 33 (1-2): 215- 221.

Petrakis, G. and Stergiou, K.I. (1995). Weight-length relationships for 33 fish species in Greek Waters. Fish. Res., 21(3-4): 465-469.

Ramirez, T.; Cortes, D.; Garcia, A. and Carpena, A. (2004). Seasonal variations of RNA/DNA ratios and growth rates of the Alboran Sea sardine larvae (Sardina pilchardus). Fish. Res., 68 (1-3): 57-65.

Ricker, W.E. (1971). Methods for assessment of fish population in fresh waters. I.B.P. Blackwell Scientific Publication, 348pp.

Ricker, W. E. (1975). Computation and interpretation of biological statistics of fish population. Bull. Fish. Res. Board Can., 191: 1- 382.

Rooker, J.R. and Holt, G. J. (1996). Application of RNA: DNA ratios to evaluate the condition and growth of larval and juvenile red drum (Sciaenops ocellatus). Mar. Freshwater Res., 47: 283-290.

Rounsefell, G.A. and Everhart, W.H. (1953). Fishery Science: Its Methods and Applications. John Wiley \& Sons, New York, 444 p.

Schreck, C. B. (1981). Stress and compensation in teleostean fishes: response to social and physical factors. In: Pickering, A.D., Ed., Stress and Fish, Academic Press, London, pp. 295-321.

Shalloof, K. A. Sh. and El- Far, A. M. (2017). Length-Weight Relationship and Condition Factor of Some Fishes from the River Nile in Egypt with Special Reference to Four Tilapia Species. Egypt. J. Aquat. Biol. \& Fish., 21(2): 33-46.

Smith, T.R. and Buckley, L.J. (2003). RNA- DNA ratio in scales from juvenile cod provides a nonlethal measure of feeding condition. Trans. Am. Fish. Soc., 132: 9- 17.

Tanaka, Y.; Satoh, K.; Yamada, H.; Takebe, T.; Nikaido, H. and Shiozawa, S. (2008). Assessment of the nutritional status of field-caught larval Pacific blue fin tuna by RNA/DNA ratio based on a starvation experiment of hatcheryreared fish. J. Exp. Mar. Biol. Ecol., 354(1): 56-64.

Teichert-Coddington, D.R.; Popma, T.P. and Lovshin, L.L. (1997). Attributes of tropical pond cultured fish. In HS Egna, CE Boyd, eds. Dynamics of Pond Aquaculture. CRC Press, Boca Raton, FL, USA, pp. 183-198.

vanRensburg, K. J. (1966). Growth of Tilapia mossambica (Peters) in de Hoop Vlei and Zoekotevlei. Dept. of Nat. Cons. Cape of Good Hope Investl. Rep., 9:1-7.

Wang, H.; Chang, G.; Qiang, J. and Xu, P. (2017). Relationship of RNA/DNA ratio to somatic growth of Nile tilapia juveniles (Oreochromis niloticus) under joint effects of temperature and salinity. Aquac. Res., 48(6): 2663-2671.

Wootton, R.J. (1992). Fish Ecology. Blackie, Glasgow and London, Publ. Chapman \& Hall, New York. 


\section{ARABIC SUMMARY}

\section{دراسة على النمو والوفيات ومعدل بيوكيميائى كدليل للنمو في اسماك البلطى النيلي " Oreochromis} niloticus

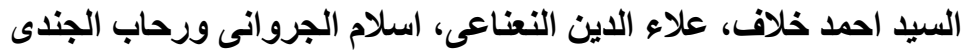

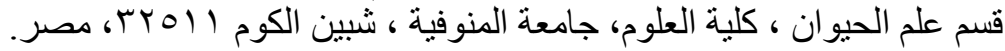

تولت هذه الدراسة النمو ومعدلات الوفيات، وكفائة معدل الدنا على الرنا فى وصف النى النمو فى اسماك

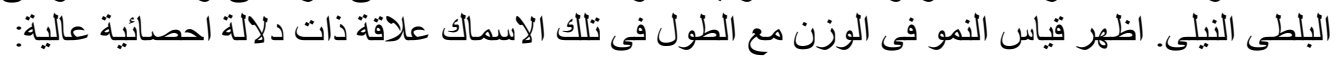

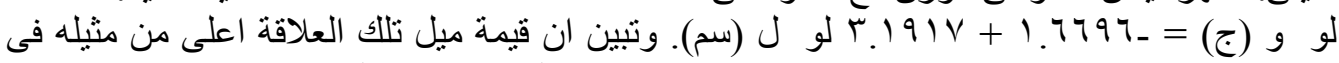

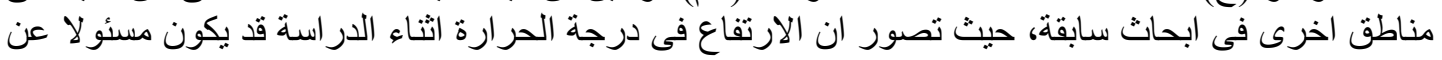
ذلك.

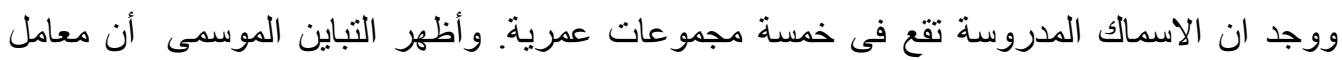

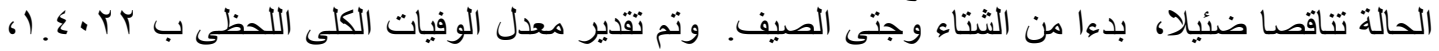

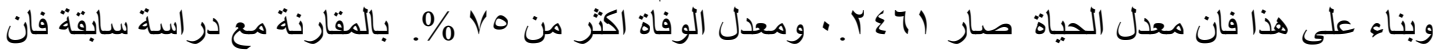

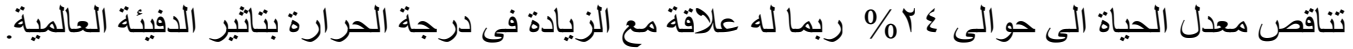

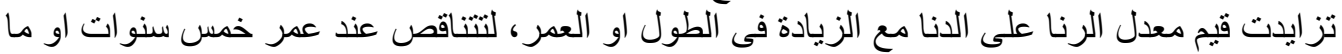

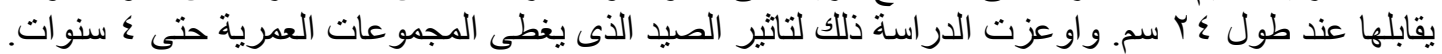

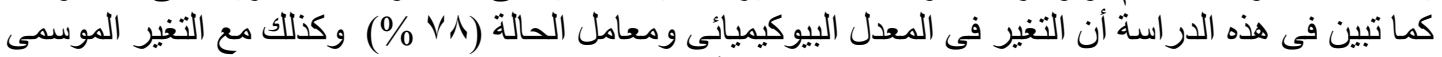

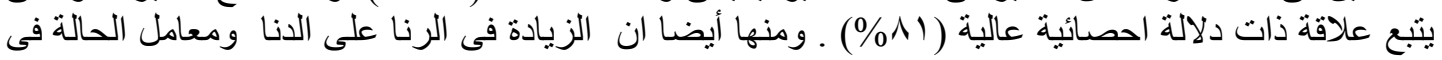

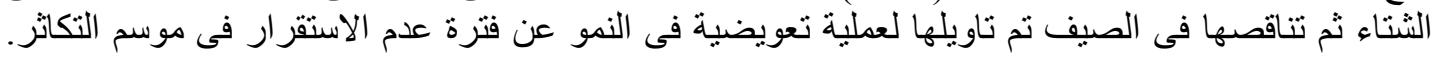

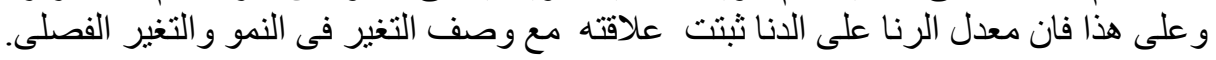

